\title{
Emotional aspects present in the lives of amputees: a literature review
}

\author{
Maíra Frizzi da Cunha Bergo' \\ Pontifical Catholic University of Campinas, SP, Brazil \\ Helena Bazanelli Prebianchi \\ Pontifical Catholic University of Campinas, SP, Brazil
}

\begin{abstract}
The systematization of knowledge about emotional aspects in amputation surgery situation shows itself necessary, both for preparation and professional training of psychologists who act in the area and for the patients involved. Objective: literature review about emotional aspects in life of patients submitted to limb amputation. Method: literature review, prioritizing a retrospective character. The selection was made based in indexers of scientific production (PePSIC, SciELO, LILACS), covering the period 2009-20 14. Results: Ten studies were found so there is a scarcity of publications about the theme; the publications are majority in periodicals focused on Nursery; the studies do not include the family relations or relation doctor-patient; most of them treat about the emotional aspects of the patient during the period of postoperative. Final consideration: the scarcity of works, such as the characteristics of those that already exist, point to the necessity of new and refined studies.
\end{abstract}

Keywords: amputation; psychology; emotional aspects; surgery; family.

\section{ASPECTOS EMOCIONAIS PRESENTES NA VIDA DE PACIENTES SUBMETIDOS À AMPUTAÇÃO: UMA REVISÃO DE LITERATURA}

\begin{abstract}
Resumo: A sistematização do conhecimento sobre os aspectos emocionais em situação de cirurgia de amputação mostra-se necessária, tanto para a preparação e capacitação dos psicólogos que atuam na área como para os pacientes envolvidos. Objetivo: revisão de literatura sobre os aspectos emocionais presentes na vida de pacientes submetidos à amputação de membros. Método: revisão de literatura, priorizando um caráter retrospectivo. Os trabalhos foram selecionados em indexadores de produção científica (PePSIC, SciELO, LILACS), cobrindo o período de 2009 a 20I4. Resultados: Dez artigos foram encontrados. Constatou-se que há escassez de publicações sobre o tema e as existentes, em sua maioria, são em periódicos de Enfermagem, não incluindo aspectos sobre relações familiares ou relação médico-paciente; a maior parte deles trata sobre os aspectos emocionais do paciente no período pós-operatório. Considerações finais: a escassez de trabalhos, bem como as características dos existentes, apontam para a necessidade de novos e melhores estudos.
\end{abstract}

Palavras-chave: amputação; psicologia; aspectos emocionais; cirurgia; família.

1 Mailing address: Maíra Frizzi da Cunha Bergo: Pontifícia Universidade Católica de Campinas, Av. John BoydDunlop, s/n - Jardim Ipaussurama, Campinas, SP. E-mail: maira.fcb@puc-campinas.edu.br 


\begin{abstract}
Resumen: La sistematización de lo conocimiento sobre los aspectos emocionales en caso de cirugía de amputación se hace necesaria para la preparación y formación de los psicólogos que trabajan en el campo y para los pacientes involucrados. Objetivo: revisión de la literatura sobre los aspectos emocionales en la vida de pacientes sometidos a amputación de las extremidades. Método: revisón de la literatura, priorizando un carácter retrospectivo. Los trabajos fueron basados en índices de producción científica (PePSIC, SciELO, LILACS), que abarca el período 2009-20I4. Resultados: Fueram encontrados diez estudios. Así, hay escasez de publicaciones sobre el tema y las existentes, están en revistas de enfermería, sin incluir los aspectos de las relaciones familiar o relación médico-paciente; la mayoría de los estudios abarca los aspectos emocionales del paciente en el postoperatorio. Consideraciones finales: la falta de estudios, así como las características de los que ya existen, señala la necesidad de nuevos estudios.
\end{abstract}

Palabras clave: amputación; la psicología; lo emocional; la cirugía; la familia.

\title{
Introduction
}

Usually, a surgical procedure greatly impacts one's physical, social, and emotional well-being, leading to increased levels of anxiety and stress, given the separation, even if temporary, from social and family support networks. In surgical terms, an amputation refers to the removal of an organ or part of it, located at one end, such as tongue, breast, intestine, cervix, penis and limbs (De Luccia, Goffi, \& Guimarães, 1996). The conditions that lead to an amputation are: (a) uncontrollable infection, normally in an emergency; (b) chronic pain among patients with vascular disease without other therapeutic possibilities; (c) bones and soft tissues destroyed beyond recovery due to vascular diseases or trauma; (d) malign or benign tumors; (e) deformities with functional implications that can improve with the use of prostheses; and ( $f$ ) aesthetic deformities that can be minimized with prostheses (De Luccia et al., 1996; Kruspki \& Nehler, 2003; Marshall \& Stansby, 2007).

There are no accurate statistics in Brazil on the number of amputations performed per year, though, it is known that approximately $94 \%$ of the amputations performed in 2011 by the Brazilian Public Health System (SUS) were of the lower limbs (Ministério da Saúde, 2013).

According to the Ministry of Health (2013), the most frequent cause of amputation is vascular ( $75 \%$ in lower limbs), whether associated or not with diabetes, while amputee patients are 60 years old, on average. Traumas (20\%), prevalent in traffic accidents and firearm injuries, mostly affect young individuals of a productive age, while tumors $(5 \%)$, benign or malignant (the most common of which is osteosarcoma), most frequently affect children and adolescents, that is, individuals still in the growth phase (Ramos, Mendonça, Okamoto, \& Ingham, 2007).

The Ministry of Health (2013) states that amputation is intended to remove the affected limb and create new perspectives to improve the region with the amputation. The rehabilitation is supposed to be implemented by a multi-professional team, whose therapeutic project ensures integral care, avoiding conflicting practices. Ultimately, 
the objective is to provide integral care to the amputee, the result of which is to maintain the patient's physical and mental health, as well as autonomy and social inclusion.

In general, the preoperative procedure involves a detailed physical assessment of the patient, clarification of the functional prognosis, and discussions addressing phantom pain and rehabilitation goals in the short, medium and long terms. Some authors (Pinto, 2001; Ramos \& Salles, 2003) state that some aspects should be assessed in the preoperative period of an amputation, such as range of motion and muscle strength, both in the affected limb, as well as in the opposite limb; the patient's degree of dependency to perform Activities of Daily Living (ADLs); physical conditioning; social support; and coping strategies.

Due to the population's health conditions recorded by the Brazilian Ministry of Health (2013), the work of psychologists that is performed with amputees has grown. Whether amputation is caused by disease or trauma, it remains a complex phenomenon, the consequences of which for individuals and the rehabilitation process cannot be resolved by the use of prostheses alone (Atherton \& Robertson, 2006).

Rehabilitation programs of amputee patients cannot disregard the psychological aspects involved, for instance, changes in one's body image, personal identity, and quality of life (Senra, Oliveira, Leal, \& Vieira, 2012). A study conducted by Luchetti, Cutti, Montebarocci, Verni and Rossi (2013) reports there is a correlation between an amputee's self-image with distorted perceptions and general/social adaptation to prostheses, while this relationship also plays a significant role in a person's quality of life, particularly in regard to limited physical and mental activities.

Approaches intended to control pain, gain or maintain one's range of movement and muscle strength should be implemented whenever possible. The British Society of Rehabilitation Medicine reported in 2003 that psychological preparation of patients prior to surgery strengthens their ability to deal with the surgery and accept prostheses in the rehabilitation phase.

The care provided to a patient undergoing the amputation of limbs has some peculiarities in comparison to other surgical patients, as the process of removing a limb encompasses a complexity of psychological phenomena and interactions among patient, family and staff (Gabarra \& Crepaldi, 2009). The fear of losing a visible part of the body makes real a feeling of body disintegration. The decision to amputate a limb is difficult both for the health staff and for the patient and family (Boccolini, 1995; De Luccia, 2004). The work of psychologists helps the amputation process in the presurgery (Cavalcanti, 1994; Price \& Fisher, 2002) and post-surgery periods (Boccolini, 1995; De Benetto, Forgione, \& Alves, 2002; Price \& Fisher, 2005, 2007).

Several changes caused by an amputation may occur, such as difficulty performing basic skills and daily tasks, loss of independence, feeling of inferiority, well-being problems, negative changes in professional life, identity changes, and changes in affective or sexual life (Senra, Oliveira, Leal, \& Vieira, 2012). Sabino et al. (2013) consider that after a patient is amputated, s/he usually faces several emotional responses, 
possibly experiencing a lack of adjustment due to dealing with forced dependency and a loss of self-worth. Patients may present different responses and feelings, such as sadness, loathing, shock, rage, suicidal ideation, or acceptance (Sabino et al. 2013).

The work of psychologists in situations of amputation can be verified in studies (Horgan \& MacLachlan, 2004; Wald \& Álvaro, 2004) and interventions (Fitzpatrick, 1999; Rybarczyk, Edwards, \& Behel, 2004; Price \& Fisher, 2002, 2005, 2007). The authors (Rybarczyk, et al., 2004; Price \& Fisher, 2007) suggest longitudinal and qualitative studies to fill in the gaps in the field, such as how amputees cope in the short and long terms, and the influence of marital and social support in the rehabilitation process.

Thus, the systematization of knowledge regarding the emotional aspects of patients in situations of amputation is necessary, both to prepare and train psychologists working in the field and for the benefit of the patients involved. In this sense, this study's objective was a literature review addressing the emotional aspects present in the lives of patients undergoing limb amputation.

\section{Method}

The studies were selected based on a consultation of the Virtual Health Library VHL -Psi, composed of different databases and available through the electronic address www.bvs-psi.com.br. The following descriptors were established for the search: "psychology", "amputation", "patients", "amputees" and "emotional aspects". Descriptors were sought in the key words.

Inclusion criteria were: studies published from 2009 to 2014, including individuals who had undergone amputation (of any body part), addressing the psychological aspects of amputees, being written in English or Portuguese. In turn, exclusion criteria were: book chapters, publications in conference proceedings, and papers, the full texts of which were not available. No restrictions were established in regard to the methods used.

According to this study's nature and objectives, the papers selected were grouped into eight criteria: type of study; method; mentioning emotional aspects during hospitalization; mentioning emotional aspects in the post-operative period; mentioning emotional aspects after hospitalization; physician-patient relationship; influence of the family; and, finally, characterization of amputation. These criteria were analyzed in terms of frequency.

We also tabulated the frequency of the number of publications in the period considered under study (2009 to 2014) and the fields of the periodicals.

\section{Results}

Considering the inclusion criteria proposed for this study, 10 papers were selected. The stages of assessment and selection of papers are presented in Figure 1. 
Figure I. Stages of assessment and selection of papers

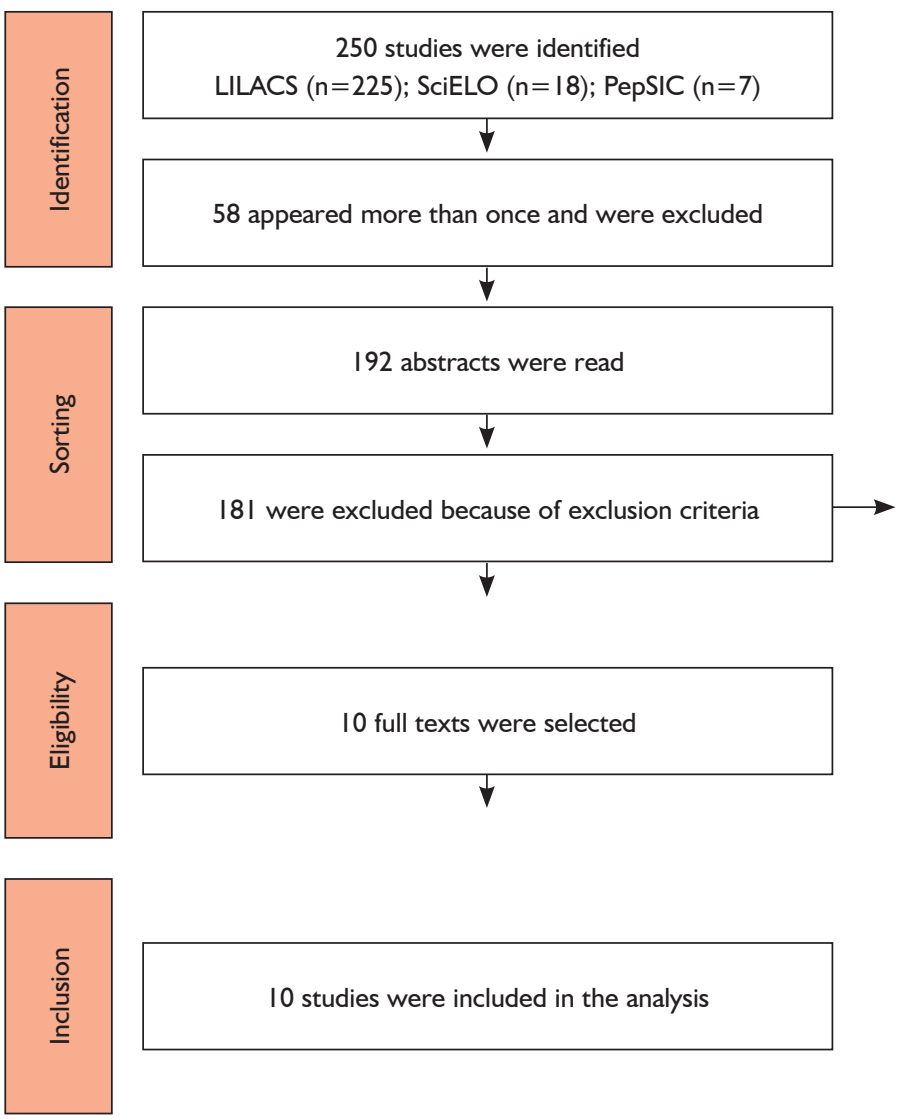

(i) Out of the study period established (2009/2014);

(ii) Does not mention the emotional aspects of patients at all;

(iii) Full-text studies written in languages other than English or Portuguese.

Source: The authors.

In regard to the number of publications, Figure 2 presents the number of studies and period of publication. The number of papers addressing the topic was greater in 2009, with an accentuated drop in 2010. There was an increase in the number of papers in 2011, which then dropped both in 2012 and 2013. Finally, in 2014, the number of studies returned to the 2011 levels, though still fewer than 2009. 
Figure 2. Number of publications in the period from 2009 to 2014

Publication year

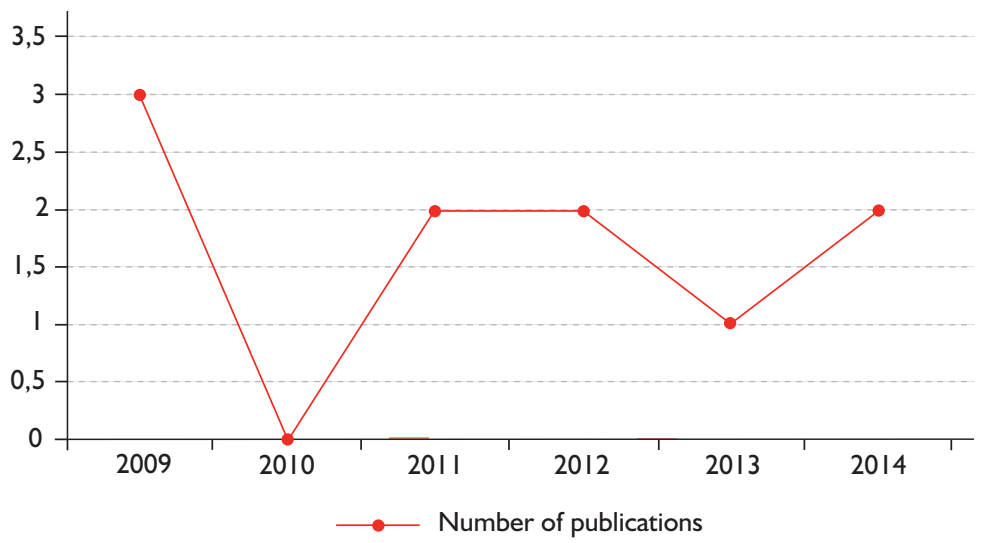

Source: The authors.

The results also show that studies were exclusively published in periodicals in the field of Nursing (4), Psychology (3), and periodicals with a multidisciplinary nature. The following results were obtained according to studies that met the inclusion criteria:

\section{Methods}

In relation to the study's method, most studies (6) are qualitative, exploratory and descriptive studies. In the remaining papers, two are case studies, one is a literature review, and one is a quantitative study.

The instrument most frequently used in the qualitative studies (5) was the semistructured interview with content analysis (Gabarra and Crepaldi, 2009; Marques et al., 2014; Sales et al., 2012; Seren \& Tilio, 2014; Vargas et al., 2013). Two studies report reflections on psychoanalytic theories (Carvalho, Serra, \& Guimarães, 2011; Galván \& Amiralian, 2009). Free association of words was used in one of the studies (Silva et al., 2009), Phenomenological interview was adopted in another study (Batista, 2012), and the World Health Organization Quality of Life Scale (WHO - QOL BREF) and Functional Independence Measure (FIM) were used in the quantitative study.

\section{Study's themes}

The themes addressed by the studies were categorized for analysis as follows.

\section{Emotional aspects during hospitalization}

This category indicates whether the paper addresses the emotional aspects of patients experienced during hospitalization and the pre-operative period and what emotional aspects were present. 
Six of the studies do not report the emotional aspects of patients during hospitalization. The most frequent emotional aspect reported (in two studies) was rejection of the surgery. Batista and Luz (2012) and Vargas et al. (2013) report that patients had problems accepting the diagnosis of amputation being necessary.

Afterwards, feelings such as sorrow, accompanied by crying, were reported in one of the studies. Seren and De Tilio (2014) report that patients experienced symptoms of depression after receiving the amputation diagnosis, such as sorrow, loss of appetite, and crying episodes. Carvalho et al. (2011) report that the patient cried profusely at the time of the diagnosis. The remaining aspects that appeared in the analysis, each mentioned in one of the studies, were: anxiety, despair, denial, suicidal ideation, depressive symptoms, and guilt.

\section{Emotional aspects in the post-operative period}

This category indicates whether the emotional aspects patients experienced in the postoperative period were addressed in the papers.

Four of the studies did not refer to emotional aspects experienced by patients in the postoperative period. The most frequently reported feeling in three papers was insecurity: Carvalho et al. (2011); Galvan and Amiralian (2009) and Sales et al. (2012) mention patients felt insecure in regard to future prospects after the surgery.

Seren and De Tilio (2014) report that when the patients woke up from the amputation surgery, they had difficulties accepting reality and cried profusely. According to Vargas et al. (2013), patients also experienced denial. In the case reported by Carvalho et al. (2011), the patient questioned how the lost limb would recover and cried a lot when $\mathrm{s} /$ he realized the limb would not regenerate. Three studies mention denial followed by sorrow and/or crying.

Feelings of incompleteness and self-esteem problems are reported by Carvalho et al. (2011), in which the patient, in addition to experiencing a self-image problem, presented a fear of being rejected by people, afraid of how people would see him. The study conducted by Seren and De Tilio (2014) reports the presence of a phantom limb sensation.

The following aspects concerning the postoperative period were reported in one paper each: Vargas et al. (2013) identified a desire of patients to become independent through the use of prostheses, while Sales et al. (2012) observed that some patients present acceptance and willingness to cope.

\section{Emotional aspects after the hospitalization}

In this category, we verified whether the papers reported the emotional aspects of patients experienced after hospitalization and which of these aspects remained beyond the postoperative period.

The most frequent emotional aspects (found in three studies) after hospitalization were distress caused by loss of independence, and consequently, caused by having to 
rely on others, and a feeling of social isolation. One participant in the study by Seren and De Tilio (2014) reported how limited he became after the amputation. The study by Silva et al. (2009) reports that the participants depicted themselves as incapable and useless because they became dependent on other people. Additionally, Batista and Luz (2012) concluded that patients experienced distress caused by dependency on others and had problems performing tasks. The feeling of social isolation appeared in the studies by Batista and Luz (2012), Gabarra and Crepaldi (2009) and Sales et al. (2012), in which patients reported prejudice and social stigmatization caused by the amputated limb and functions they were no longer able to perform. Three of the studies (30\%) did not report the emotional aspects of patients after hospitalization. The following aspects were observed in one study each: Batista and Luz (2012) report that patients experienced fear of a future surgery for amputation would be needed as a cause of diabetes; Cox et al. (2011) report that damage to self-image is inversely proportional to the severity of the amputation.

In the qualitative study conducted by Vargas et al. (2013), the experience of diabetic patients receiving group psychotherapy was reported and feelings of independence and greater acceptance were observed, together with the resumption of their activities, coping, and positive thinking after taking part in group psychotherapy.

\section{Physician-patient relationship}

This category refers to the presence or absence of a physician-patient relationship and its potential influence on the recovery of patients.

Most studies, seven out of 10 , did not report the existence of a physician-patient relationship. Of the three studies that do mention such a relationship, two present the reports of patients. Marques et al. (2014) report that patients complained of neglect and lack of information on the part of physicians in regard to the amputation surgery; the study by Batista and Luz (2012) reports that patients started to depend on their physicians' consent to make certain decisions. In another paper, Gabarra and Crepaldi, (2009) suggest the behaviors physicians could adopt to facilitate the rehabilitation process, such as individualized attention, active listening, giving opportunities for patients to ask questions, use of accessible language, encouraging the active participation of the patient in the decision-making regarding the surgery process, and embracing patients' distress.

\section{Family influences}

This category indicates whether the study reveals the presence or absence of the family in the period of hospitalization and potential influences of the family on patient recovery.

Six papers do not mention the influence of the family. Three papers, Marques et al. (2014), Seren and De Tilio, (2014) and Vargas et al. (2013) report the presence of the family as being essential for the patient to resume life and during the recovery process. 
The case study conducted by Carvalho et al. (2011) reports that the absence of the family during the patient's surgery process and rehabilitation was a negative factor because the patient reported missing his family during the time he was hospitalized.

\section{Category of amputation}

This indicates why amputation was necessary, and how many and which limbs were amputated.

Four out of ten papers report accidents in general as the etiology of amputations, while another four papers report Diabetes Mellitus as being the cause of limb amputation. Considering the other etiologies reported, thrombosis appears in two studies as being the cause of amputation. One study reports infection was the etiology of one patient mentioned in the studies and, for another, the patient reported by one of the studies, amputation was caused by three gunshot wounds.

\section{Discussion}

The studies under analysis had different objectives, while a focus on amputees was their common trait. The results concerning the number of studies reveal that, despite the fact that in 2013 the Brazilian Ministry of Health acknowledged the need to provide Guidelines for Amputee Care in order to provide guidance to multi-professional teams on the care provided to individuals who have a limb amputated, research addressing the topic is still scarce.

The results regarding the fields on which publications focus also contradicts this determination of the Ministry of Health (2013), as nurses and psychologists are the professionals who have addressed the topic, so that there has not been multi-professional or interdisciplinary interest. Considering that the care provided to surgical patients encompasses various fields of knowledge and procedures performed by different professionals, health workers should aim to compose an integrated set of care practices for the surgical procedure. In this sense, Turra et al. (2011) reinforce the importance of developing and implementing systematized ways of providing care to improve the interdisciplinary communication system.

In addition to a scarcity of studies, the methodological aspects of the studies do not favor the generalization of results or provide a solid base for knowledge concerning amputee patients, as most studies are qualitative, exploratory and descriptive. Crucial aspects, such as the impact of the physician-patient relationship and family support provided in the pre- and post-operative periods, did not receive proper attention, despite the indications for this provided by the literature.

Pereira and Azevedo (2005) interviewed 50 patients addressing their relationships with physicians and report that $35(70 \%)$ of them did not consider the information provided by the physicians to be sufficient, while 32 (64\%) patients consider the physician-patient relationship to interfere directly in how their condition progressed. Fitzpatrick (1999 cited by Gabarra \& Crepaldi (2009)) highlight aspects that are 
fundamental in the medical staff's behavior: individualized attention paid by the surgeon to the patient; active listening with an ability to observe details; creating opportunities for the patient to ask questions and respond to them honestly; accessible language; and providing pictures, videos and reading material addressing the surgery and later rehabilitation, so that the patient acquires a feeling of control and is encouraged to participate actively in the decision-making process. Rodrigues (2011) also stresses the need for physicians to establish a dialogue with patients, considering that physicians are the protagonists in hospital settings and should be the first to embrace the distress of patients. The patients addressed by Marques et al. (2014) also reported that there was no relationship with their physicians during hospitalization because they did not receive the information they need in regard to what was happening to their bodies. The need for such a relationship is highlighted by Batista and Luz (2012), who concluded that some patients tend to transfer their responsibilities to the physician and depend on their consent to perform certain tasks, therefore, it is necessary that a relationship be established between the physician and patient to answer all the questions patients might have.

The findings of Pereira and Azevedo (2005) indicate that the impact of a physician-patient relationship on the rehabilitation of amputees were confirmed by Morais (2014), whose interviews reveal that efficacious communication with the medical staff through the transmission of accurate information facilitated the process of accepting the amputation for some of the study's participants. Bearing in mind that this study's results indicate that the most frequent feeling is denial, the importance of a physician-patient relationship is highlighted due to the positive effects of good communication. For this reason, the Ministry of Health notes in its guidelines:

At the time of disclosing the news to the family and patient who will undergo the amputation surgery, it should be stressed that the surgery is an important part of treatment. Needs and positive aspects in terms of quality of life should be presented. A team of qualified professionals is essential to addressing the subject in order to enable the adaptation of both patient and family to the new situation (Ministério da Saúde, 2013, p. 22).

Additionally, according to the Ministry of Health (2013), the patient should be informed about how the amputated body part will be disposed of. In Brazil, it can be buried, or when the patient consents, be used for studies and research. Being aware of how the amputated limb will be disposed facilitates acceptance of the process on the part of patients (Ministério da Saúde, 2013).

The limited visibility given to family relations in the studies addressed here constitutes a gap that hinders understanding and attention provided to amputees. Rodrigues (2011) notes that a patient's social identity may be affected in terms of the roles an individual plays professionally and at home. Clearly, the family is crucial in the process of development of the individuals who compose it (Guimarães, 2015). The family helps to understand healthy or risky habits, coping strategies, and how the disease is 
experienced. Therefore, a family's responses influence the patient's establishment of new identity references.

This study's results indicate that the emotional aspects that accompany the amputation process differ from patient to patient and also depend on the etiology of amputation, which corroborates the study by Turra et al. (2011), which shows that the personal life and historical-social moment impact the pathogenicity of the disease and interpretation of symptoms on the part of patients. Patients who undergo surgery due to vascular diseases, for instance, may feel relieved that they no longer have to deal with the pain they felt in the removed limb. Rodrigues (2011) reports that patients attending group psychotherapy who underwent amputations caused by vascular diseases report less anguish with the cessation of pain and possibility of a cure, while, according to the author, patients who suffer an amputation due to traumas react differently and experience greater anxiety and uncertainty in regard to future prospects. Carvalho et al. (2011) present a case report of a 14-year-old patient who had his right forearm amputated due to an electrical shock and report that this patient questioned how his life would be in the future and also presented issues regarding his self-image.

Another issue that diverges depending on the responses of patients to amputation and data collected by the authors is the use of prostheses. Some patients show much hope after the surgery because they believe they will regain their independence with the use of prostheses, as was the case of the study conducted by Rodrigues (2009). The patient believed that the prostheses would enable her to be more independent, so she felt renewed energy to perform activities.

On the other hand, Rodrigues (2011) also reports that many amputees undergoing rehabilitation with prostheses refused to use a prosthesis due to several factors, such as pain in the stump and difficulty adapting. Experts, however, insisted on the use of prostheses, believing that the devices would be the best solution for patients who lost a limb, regardless of their will (Rodrigues, 2011).

\section{Final Considerations}

This study's objective was to perform a literature review addressing the emotional aspects present in the lives of patients who underwent the amputation of limbs. We expected to identify the presence of emotional aspects, such as anxiety, depression, coping strategies, self-image issues, and body reintegration in the amputation process, in order to contribute to the practice of psychologists working within an interdisciplinary team.

The results, however, indicate a scarcity of studies addressing the topic, while the existing studies presented limited methodological characteristics and little consideration given to aspects that are crucial in the coping process of amputees and their rehabilitation. Even though this review is restricted by the small number of papers and a lack of more recent data from the Ministry of Health, it shows there is still a long way to go to acquire a deeper understanding of amputees in order to meet their needs. 
The gaps existing in this field, such as coping strategies in the short and long terms, the influence of family and social support on one's rehabilitation, and the extent to which prostheses cause subjective distress, are challenges researchers and health workers have to face to implement larger and improved studies addressing the topic.

\section{References}

Atherton R., \& Robertson N. (2006). Psychological adjustment to lower limb amputation amongst prothesis users. DisabilityRehabilitation, 28, 1201-1209.

Batista, N. N. L. A. L., \& Luz, M. H. B. A. (2012). Vivências de pessoas com diabetes e amputação de membros. Revista Brasileira de Enfermagem, 65(2), 244-250.

Boccolini, F. (1995). Reabilitação do amputado. In: F. H. A. Maffei (Org.), Doenças Vasculares Periféricas (pp. 257-281, 2nd ed). Tijuca: MEDSI.

British Society of Rehabilitation Medicine. (2003). Amputee and Prosthetic Rehabilitation: Standards and Guidelines (2nd ed). London: BSRM.

Carvalho, I. D., Serra, M. C., \& Guimarães Jr., L. M. (2011). Amputação: as indagações do sujeito. Rev Bras Queimaduras, 10(4), 141-143.

Cavalcanti, M. C. T. (1994). Aspectos emocionais no pré-operatório em amputação de membros. Jornal Brasileiro de Psiquiatria, 43(3), 159-161.

Cox, P. S. L., Williams, S. K. P., \& Weaver, S. R. (2011). Life after lower extremity amputation in diabetics. West Indian Med, 60(5), 536.

De Benetto, K. M., Forgione, M. C. R., \& Alves, V. L. R. (2002).Reintegração corporal em pacientes amputados e a dor fantasma. Acta Fisiátrica, 9(2), 85-89.

De Luccia, N. (2004). Amputações e a doença vascular periférica. Jornal Vascular Brasileiro, 3(3), 179-180.

De Luccia, N., Goffi, F. S., \& Guimarães, J. S. (1996). Amputação de membros. In F. S. Goffi (Coord.). Técnica cirúrgica: bases anatômicas, fisiopatológicas e técnicas de cirurgia (pp. 180-187, 4th ed). São Paulo: Atheneu.

Fitzpatrick, M. (1999). The psychologic assessment and psychosocial recovery of the patient with an amputation. Clinical Orthopaedics and Related Research, 361, 98-107.

Gabarra, L. M., \& Crepaldi, M. A. (2009). Aspectos psicológicos da cirurgia de amputação. RevAletheia, 30, 59-72.

Galván, G. B., \& Amiralian, M. L. T. M. (2009). Corpo e identidade: reflexões acerca da vivência de amputação. Estudos de Psicologia, 26(3), 391-398.

Guimarães, C. A. (2015). Cuidadores familiares de pacientes oncológicos pediátricos em fases distintas da doença: Processo de enfrentamento (Tese de Doutorado em Psicologia). Pontifícia Universidade de Campinas, Campinas-SP. 
Horgan, O., \& MacLahan, M. (2004). Psychosocial adjustment to lower-limb amputation: a review. Disability and Rehabilitation, 26(14/15), 837-850.

Krupski, W. C., \& Nehler, M. R. (2003). Amputation. In L. W. Way \& G. M. Doherty (Orgs.), Current: surgical diagnosis \& treatment (pp. 859-870). New York: Lange Medical Books.

Luchetti M., Cutti A. G., Montebarocci O., Verni G., \& Rossi N. C. F. (2013). Reazioni psicologiche in soggetti com amputazione di arto: una rassegna della letteratura. Psicologia dellasalute, 1, 49-70.

Marques, A. M. F. B., et al. (2014). Health Care for people with amputation: analysis from the perspective of bioethics. Text Context Nursing, 23(4), 898-906.

Marshall, C., \& Stansby, G. (2007). Amputation. Surgery, 26(1), 21-24.

Ministério da Saúde; secretaria de atenção à saúde; departamento de ações programáticas estratégicas. (2013). Diretrizes de atenção à pessoa amputada (1ª ed). Brasília: Distrito Federal.

Morais, Z. M. (2014) Implicações psicossociais da amputação dos membros inferiores nos utentes diabéticos no Hospital Dr. Bapstista de Souza. (Trabalho apresentado à Universidade do Mindelo como parte dos requisitos para obtenção do grau de Licenciada em Enfermagem). Universidade do Mindelo, Cabo Verde.

Pereira, M. G. A. P., \& Azevedo, E. S. (2005). A relação médico-paciente em Rio Branco/AC sob a ótica dos pacientes. RevAssocMedBras, 51(3), 153-157.

Pinto, M. A. G. (2001) A Reabilitação do Paciente Amputado. In Lianza S. (Ed.), Medicina de Reabilitação. ( $3^{a}$ ed). Rio de Janeiro: Guanabara Koogan.

Price, E. M., \& Fisher, K. (2002). How does counseling help people with amputation? Journal of Prosthetics and Orthotics, 14(3), 102-101-106.

Price, E. M., \& Fisher, L. (2005). Additional studies of emotional needs of amputees. Journal of Prosthetics and Orthotics, 17(2), 52-56.

Price, E. M., \& Fisher, L. (2007). Further study of the emotional needs of amputees. Journal of Prosthetics and Orthotics, 19(4), 106-108.

Ramos, A. C., \& Salles, I. C. (2003) Amputações de Membros Superiores. In E. Teixeira et al. (Ed.), Terapia Ocupacional na Reabilitação Física. São Paulo: Rocca.

Ramos, A. C. R., Mendonça, A. B., Okamoto, A. M., \& Ingham, S. J. M. (2007). Amputações. In A. C. Fernandes, A. C. R. Ramos, M. E. P. Casalis, \& S. K. Hebert. Medicina e reabilitação: princípios e práticas (pp. 207-229). São Paulo: Artes Médicas.

Rodrigues, S. R. (2009). Corpo deficiente e individuação: um olhar sobre pessoas com deficiência física adquirida a partir da psicoterapia breve de orientação junguiana. ( Dissertação de Mestrado). Instituto de Psicologia, Universidade de São Paulo, São Paulo-SP. 
Rodrigues, S. R. (2011). Uma psicanalista em uma equipe multidisciplinar: atendimento a pacientes com amputação em reabilitação com prótese. (Dissertação de Mestrado). Instituto de Psicologia, Universidade de São Paulo, São Paulo-SP.

Rybarczyk, B., Edward, R., \& Behel, J. (2004). Diversity in adjustment to a leg amputation: case illustration of common themes. Disability and Rehabilitation, 26(14/15), 944-953.

Sabino, S. M., Torquato, R. M., \& Pardini, A. C. G. (2013). Ansiedade, depressão e desesperança em pacientes amputados de membros inferiores. Acta Fisiátrica, 20(4), 224-228.

Sales, L. M. R. et al. (2012). Repercussões psicossociais da amputação: concepções de pessoas que as vivenciam. Revista de pesquisa: cuidado é fundamental, 4(4), 315-326.

Senra, H., Oliveira, R. A., Leal, I., \& Vieira, C. (2012). Beyond the body image: a qualitative study on how adults experience lower limb amputation. ClinRehabil, 26(2), 180-190.

Seren, R., \& De Tilio, R. (2014). As vivências do luto e seus estágios em pessoas amputadas. SPAGESP, 15(1), 64-78.

Silva, S. E. D. et al. (2009). Meu corpo dependente: representações sociais de pacientes diabéticos. Revista Brasileira de Enfermagem, 63(3), 404-409.

Turra, V. et al. (2011). Contribuições da Psicologia na atenção ao paciente cirúrgico: uma análise da literatura. Com. Ciências da Saúde, 22(4), 353-366.

Vargas, S. R. S. et al. (2013). Psicoterapia de grupo para pacientes diabéticos amputados e seus cuidadores. Arquivos Médicos dos hospitais e da Faculdade de Ciências Médicas da Santa Casa de São Paulo, 58, 1-5.

Wald, J., \& Álvaro, R. (2004). Psychological factors in work-related amputation: considerations for rehabilitation counselors. Journal of Rehabilitation, 70(4), 6-15.

Submission: 3.3.2017

Acceptance: 1.11.2017 